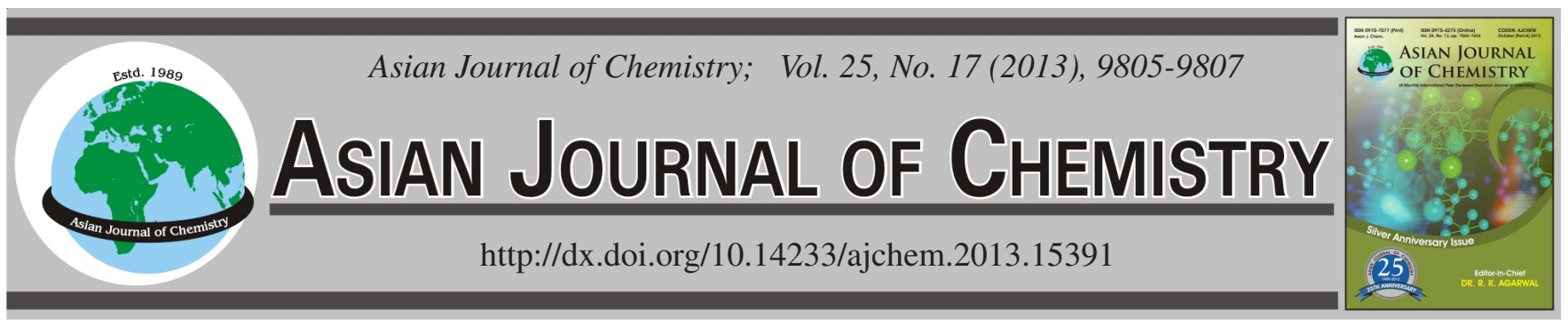

\title{
Tween-80 Medium-Spectrophotometric Determination of Trace Ge(IV) with 1-(4-Antipyrine)-3-(2,4,6-tribromo phenyl)triazene as Colour Reagent
}

\author{
Xue-Hong Zhang ${ }^{1, *}$ and Wen-Bin Chen $^{2}$
}

\begin{abstract}
${ }^{1}$ School of Chemistry and Life Science, Guangxi Teachers Education University, Nanning 530001, P.R. China
\end{abstract}
${ }^{2}$ Department of Chemical Engineering Huaihai Institute of Technology, Lianyungang 222005, P.R. China

*Corresponding author: Tel: +86 13912168711; E-mail: lygcwb11@163.com

(Received: 27 February 2013;

Accepted: 23 October 2013)

AJC-14279

\begin{abstract}
A new triazene reagent 1-(4-antipyrine)-3-(2,4,6-tribromo phenyl)triazene was studied along with the colour reaction of 1-(4-antipyrine)3-(2,4,6-tribromo phenyl)triazene with Ge(IV) in the presence of Tween-80. A highly sensitive new spectrophotometric method for the determination of trace $\mathrm{Ge}(\mathrm{IV})$ has proposed. The results showed that in $\mathrm{Na}_{2} \mathrm{~B}_{4} \mathrm{O}_{7}-\mathrm{NaOH}$ medium at $\mathrm{pH} 9.50$, the new colour reagent reacts with $\mathrm{Ge}(\mathrm{IV})$ to form a red complex (1:2). The maxium absorption wavelength and apparent molar absorptivity are $498 \mathrm{~nm}$ and $2.9 \times 10^{5}$ $\mathrm{L} \mathrm{mol}^{-1} \mathrm{~cm}^{-1}$, respectively. Beer's law is obeyed in the range of 0.01 to $2.8 \mu \mathrm{g} / 10 \mathrm{~mL}$ for $\mathrm{Ge}(\mathrm{IV})$. The colour reaction system could tolerate many interfering ions due to the existence of ammonia, the detection limit is $0.006 \mu \mathrm{g} / 10 \mathrm{~mL}$. The RSD and recovery were $2.14-2.42 \%$ $(n=6)$ and $103.2-104.1 \%$. The method has been applied to the determination of trace amount of Ge(IV) in tea.
\end{abstract}

Key Words: 1-(4-antipyrine)-3-(2,4,6-tribromo phenyl)triazene, Spectrophotometry, Ge(IV).

\section{INTRODUCTION}

Trace element germanium has anticancer, antiaging properties and improve the body's immune and other physiological functions, in medicine, clinical medicine, food health products in areas such as the increasing number of applications. There are many methods for germanium determination such as atomic absorption spectrometry (AAS) ${ }^{1}$, atomic emission spectrometry ${ }^{2}$, polarographic analysis ${ }^{3}$, inductively coupled plasma mass (ICP-MS) ${ }^{4}$, spectrofluorimetry ${ }^{5}$ and spectrophotometry. Now there have been some methods for the spectrophotometric determination of germanium such as rhodanine ${ }^{6}$, porphyrin $^{7}$, fluorone ${ }^{8-10}$, etc. But its sensitivity rarely reaches $10^{-5}$ which leads to its application is limited. To further investigate the analytical performance of these reagents, this paper reports a readily available method for synthesis of 1-(4-antipyrine)-3-(2,4,6-tribromo phenyl)triazene (ATTBPT). The colour-developing reaction condition of determination of $\mathrm{Ge}(\mathrm{IV})$ with ATTBPT was studied systematically in the paper. Tween-80 further improved the selectivity and sensitivity of this method. The apparent molar absorptivity measured in the experiment is $1.8 \times 10^{5} \mathrm{~L} \mathrm{~mol}^{-1} \mathrm{~cm}^{-1}$. It is one of the highly sensitive systems in the determination of Ge(IV) at home and abroad as reported and the presence of common ions in large quantity, including many precious metal ions. Most of the metal ions can be tolerated in considerable amounts without any masking reagents, especially large amounts of Mo and W don't interfere the determination of Ge(IV). Moreover, colour system has excellent selectivity and stability. The proposed method is simple, fast and selective and has been applied to the determination of trace amounts of germanium in tea and zinc concentrate samples with satisfactory results.

\section{EXPERIMENTAL}

UNICO-7200 model spectrophotometer (Shanghai fifth instruments factoryChina) pHS-3 acidity meter (Shanghai Jingkeleici Corporation). A standard stock solution of Ge(IV) (1.0 $\mathrm{mg} \mathrm{mL}^{-1}$ ) was prepared That admission metal germanium $0.1000 \mathrm{~g}$ in $250 \mathrm{~mL}$ beaker, add $(1+4) \mathrm{H}_{2} \mathrm{O}_{2} 20-30 \mathrm{~mL}$, heating it in the water bath solution (again dropping a few drops of $\mathrm{NH}_{3} \cdot \mathrm{H}_{2} \mathrm{O}$ can accelerate decomposition). Augend $\mathrm{mL}$ of hot water, using $(1+1)$ dilute $\mathrm{HCl}$ and acidified excessive 2-3 $\mathrm{mL}$, boiled drive to hydrogen peroxide,cooling, into $1000 \mathrm{~mL}$ calibrated flask, diluted with water to calibration, shaking. When diluted with distilled water to the solution to $1.0 \mu \mathrm{g} /$ $\mathrm{mL}$; Tween-80:20 g/L; ATTBPT solution: weighed $0.25 \mathrm{~g}$ colour reagent,dissolved with ethanol then moved into 250 $\mathrm{mL}$ volumetric flask, diluted with ethanol to scale and shake, its concentration was $2.9 \times 10^{-3} \mathrm{~mol} / \mathrm{L}$.

Reagents all above were of analytical grade, water used in the test was double distilled water. 
Methods: $1 \mu \mathrm{g}$ of $\mathrm{Ge}(\mathrm{IV})$ was transferred into a $10 \mathrm{~mL}$ calibrated $1.5 \mathrm{~mL}$ flask $\mathrm{pH} 9.50$ of buffer solution, $1.2 \mathrm{~mL}$ of Tween-80 solution and $2 \mathrm{~mL}$ of 1-(4-antipyrine)-3-(2,4,6tribromo phenyl)triazene (ATTBPT) was added successively, then it was diluted to mark with water and mixed well and stood for $5 \mathrm{~min}$. The absorbance of the coloured solution was measured at $498 \mathrm{~nm}$ in a $1 \mathrm{~cm}$ pathlength against a reagent blank.

\section{RESULTS AND DISCUSSION}

Absorption spectra: The absorption spectra of the reagent ATTBPT and Ge(IV)- ATTBPT complex were shown in Fig. 1. It was evident that the maximum absorption of ATTBPT was at $350 \mathrm{~nm}$ while that of the Ge(IV)-ATTBPT and Ge(IV)- ATTBPT-Tween-80 complex were at $475 \mathrm{~nm}$ and 498. The contrast of the two peaks was $148 \mathrm{~nm}$ and can be obviously distinguished. So the absorption peak $498 \mathrm{~nm}$ was chosen as determination wavelength.

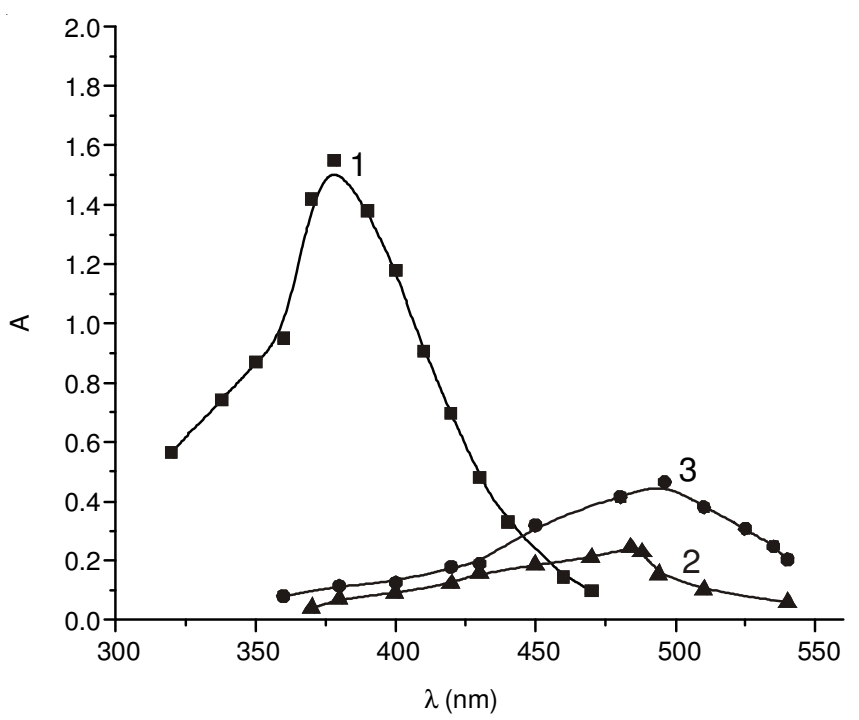

Fig. 1. Absorption spectra. 1. Reagent blank/water, 2. Ge(IV)- ATTBPT/ reagent blank, 3. Ge(IV)-ATTBPT-Tween-80/reagent blank

Effects of pH: A series of solution with different values of $\mathrm{pH}$ were prepared to determine the influence of $\mathrm{pH}$ solutions $\left(\mathrm{Na}_{2} \mathrm{SO}_{3}, \mathrm{NaOH}, \mathrm{CH}_{3} \mathrm{COOH}-\mathrm{CH}_{3} \mathrm{COONa}, \mathrm{H}_{3} \mathrm{BO}_{3}-\mathrm{NaOH}\right.$, $\mathrm{NH}_{3} \cdot \mathrm{H}_{2} \mathrm{O}-\mathrm{NH}_{4} \mathrm{Cl}, \mathrm{Na}_{2} \mathrm{~B}_{4} \mathrm{O}_{7}-\mathrm{HCl}, \mathrm{Na}_{2} \mathrm{~B}_{4} \mathrm{O}_{7}-\mathrm{NaOH}$ ) on the absorbance of the complex. The results show that the complex was almost unchanged in the $\mathrm{pH}$ range of 9.00-9.80,therefore the buffer solution of $\mathrm{Na}_{2} \mathrm{~B}_{4} \mathrm{O}_{7}-\mathrm{NaOH}$ with $\mathrm{pH}$ 9.50. From 1.3$1.8 \mathrm{~mL}$ the absorbance of the complex was largest and keeped constant,in this study $1.5 \mathrm{~mL}$ was chosen as reactive dose.

Effect of amount of reagent ATTBPT: With the increase of the volume of ATTBPT solution,the absorbance increased rapidly, followed by remaining almost at a maximum and unchanged.within $10 \mathrm{~mL}$ range of solution, the addition of 1.8-2.4 mL solution gave maximum and constant absorbance, thus an addition of $2 \mathrm{~mL}$ ATTBPT solution was recommended.

Effect of surfactants: Effect of the surfactants, it was found that in the presence of $0.8-1.6 \mathrm{~mL}$ Tween- 80 gave maximum and constant absorbance. Thus an addition of 1.2 $\mathrm{mL}$ of Tween-80 is recommended.
Effect of the order of joining the reagent and time on system absorbance: The proposed method was used for determination of the effect of the order of joining the reagent on system absorbance. It was found that the effect of absorbance was largest and accorded the experimental method was better. The maximum and constant absorbance was obtained after 5 min and which keep unchanged for $6 \mathrm{~h}$.

Composition of the Ge(IV)-ATTBPT complex: By the mole ratio, continuous variation method was determined the composition of the complex to be $n(\mathrm{Ge}(\mathrm{IV})): n(\mathrm{ATTBPT})=$ 1:2 under the experimental conditions.

Effect of co-existent ions: When the error of determining $1 \mathrm{mg} \mathrm{Ge}(\mathrm{IV})$ in $10 \mathrm{~mL}$ solution was within the tolerable limit (not more than $5 \%$ ) the maximum amount $(\mathrm{mg}$ ) of coexistent ions was permitted as follows $\mathrm{K}^{+}(50000) ; \mathrm{Na}^{+}$(4 5000); $\mathrm{Ca}^{2+}$ (5000); $\mathrm{Mg}^{2+}(3000) \mathrm{Ba}^{2+}(2000) ; \mathrm{Cd}^{2+}(500) ; \mathrm{Pb}^{2+}(300)$; $\mathrm{Pd}^{2+}$, $\mathrm{Al}^{3+}$ (200); $\mathrm{Co}^{2+}, \mathrm{Cu}^{2+}(150) ; \mathrm{Mn}^{2+}(120) ; \mathrm{Ni}^{2+}(100) ; \mathrm{Mo}^{6+}$, $\mathrm{Zn}^{2+}$ (90); $\mathrm{Cr}(\mathrm{f} !)(80) ; \mathrm{Bi}^{3+}(70) ; \mathrm{Pt}^{2+}(60) ; \mathrm{Sr}^{2+}, \mathrm{In}^{3+}(50) \mathrm{Ag}^{+}$, $\mathrm{Sb}^{3+}(45) ; \mathrm{Zr}(\mathrm{IV}), \mathrm{Ti}(\mathrm{IV})(40) ; \mathrm{Ga}^{3+}(35) ; \mathrm{Fe}^{3+}(30) ; \mathrm{W}^{3+}(25)$; $\mathrm{Ru}^{3+}, \mathrm{Sn}^{4+}(20) ; \mathrm{Zn}^{2+}(18) ; \mathrm{Au}^{3+}, \mathrm{Rh}^{3+}$ (15); Os(III) (10); V(V) (8); $\mathrm{Hg}^{2+}$ (5); $\mathrm{Nb}(\mathrm{V})$ (3); $\mathrm{La}^{3+}$ (2.5); triethanolamine (5000); tartrate (3000); citrate (2000); $\mathrm{SO}_{4}{ }^{2-}, \mathrm{PO}_{4}{ }^{3-}, \mathrm{NO}_{3}{ }^{-}, \mathrm{NO}_{2}{ }^{-}$and EDTA have no influence on the determination of $\mathrm{Ge}(\mathrm{IV})$. Experimental results showed that interference of $0.3 \mathrm{mg} \mathrm{Cu}^{2+}$, $0.25 \mathrm{mg} \mathrm{Fe}^{3+}, 0.2 \mathrm{mg} \mathrm{Hg}^{2+}$ could be eliminated efficientlyand by addition of $0.5 \mathrm{~mL} 2 \mathrm{~g} / \mathrm{L}$ EDTA.

Working curves: A series of Ge(IV)solution was prepared in accordance with the experimental procedure. Beer's law is obeyed for $0.01 \sim 2.8 \mu \mathrm{g} \mathrm{Ge}(\mathrm{IV})$ in $10 \mathrm{~mL}$ of volume at 498 $\mathrm{nm}$. The linear regression calibration equationis: $\mathrm{A}=0.2650 \rho$ $(\mathrm{mg} / 10 \mathrm{~mL})+0.0016$ with a correlation coefficient of 0.9999 . The apparent absorptivity obtained is $2.9 \times 10^{5} \mathrm{~L} \mathrm{~mol}^{-1} \mathrm{~cm}^{-1}$ and method detection limit was $0.006 \mu \mathrm{g} / 10 \mathrm{~mL}$.

\section{Sample analysis}

Analysis of tea samples: From a certain amount of tea in $1000{ }^{\circ} \mathrm{C}$ in the oven drying, the ground, accurate sample $1 \mathrm{~g}$ placed that in $100 \mathrm{~mL}$ conical flask. By adding $10 \mathrm{~mL}$ concentrated $\mathrm{HNO}_{3}$, after heating for $2 \mathrm{~h}$ at low temperature distillation unit connected, returning to digest solution clarified that the distillation removed to allow heating of volatile nitrate. Solution left overs 1-2 mL, by drop let $\mathrm{H}_{2} \mathrm{O}_{2}$, when the solution was colourless state and stop dropping to reach completely dry and cold to room temperature, by adding appropriate distilled water dissolved solids, joined $15 \mathrm{~mL} 9$ mol L ${ }^{-1} \mathrm{HCl}$, shaking after the addition of $10 \mathrm{~mL} \mathrm{CCl}_{4}$, oscillation $5 \mathrm{~min}$ for extraction, static hierarchical separation $\mathrm{CCl}_{4}$ in after another funnels, by adding $10 \mathrm{~mL}$ of water extraction after transfer to $25 \mathrm{~mL}$ calibrated flask, constant volume shaking to admit $2 \mathrm{~mL}$ solution. The results were shown in Table-1.

\section{Conclusion}

The method has been used for the determination of trace $\mathrm{Ge}(\mathrm{IV})$ in tea samples with satisfactory results and the result was in accordance with that of the recommend spectrometry method. 
TABLE-1

DETERMINATION RESULTS OF GERMANIUM(IV) IN TEA SAMPLES $(\mathrm{n}=6)$

\begin{tabular}{cccccc}
\hline Sample & $\begin{array}{c}\text { Recommend } \\
(\mu \mathrm{g} / \mathrm{L})\end{array}$ & $\begin{array}{c}\text { Present method } \\
(\mu \mathrm{g} / \mathrm{L})\end{array}$ & $\begin{array}{c}\text { Average } \\
(\mu \mathrm{g} / \mathrm{L})\end{array}$ & $\begin{array}{c}\text { RSD } \\
(\%)\end{array}$ & $\begin{array}{c}\text { Added Ge(IV) } \\
(\mu \mathrm{g})\end{array}$ \\
\hline Tea-1 & 6.21 & $6.22,6.23,6.25,6.25,6.26,6.28$ & 6.25 & 2.14 & 1.0 \\
Tea-2 & 5.24 & $5.23,5.25,5.26,5.26,5.28,5.30$ & 5.26 & 103.2 & 2.42 \\
\hline
\end{tabular}

\section{REFERENCES}

1. L.-A. Zhou, M.-J. Cao and N. Tang, Chin. J. Anal. Lab., 20, 87 (2001).

5. D.-C. Luo and J.-F. Liu, Chem. Reagents, 29, 297 (2007).

6. X.-W. He, S.-W. Bi and H. Wang, J. Anal. Sci., 21, 298 (2005).

2. H.-X. Dong, X.-S. Zhao and A.-N. Sun, J. Jilin Agric. Univ., 27, 79 (2005).

3. Y.-M. Bao, D.-Q. Zhao and L. Zhang, Chin. J. Spectrosc. Lab., 22, 979

7. W.-B. Chen, X.-Y. Xu and W.-X. Ma, Chin. J. Anal. Lab., 24, 6 (2005).

8. X. Zhou, Z.-J. Li and H.-Z. Liu, Chin. J. Anal. Lab., 25, 101 (2006).

9. Y. Sai, S. Li and F.-B. Han, Spectrosc. Spectra Anal., 24, 1404 (2004).

10. B. -H. Li, G.-H. Wang and J.-X. Jia, Chem. Res. Appl., 14, 242 (2002). (2005)

4. Y.-X. Liu, Q. Zhang and Z.-Y. Huang, Chin. J. Spectrosc. Lab. Chem. World, 1, 16 (2006). 